\title{
ANALISIS PERBANDINGAN 3 MATERIAL SHAFT DRIVER HAMMER MILL TEPUNG BERAS DENGAN KECEPATAN 1465 rpm MENGGUNAKAN APLIKASI SOFTWARE “AUTODESK INVENTOR PROFESSIONAL 2015”
}

\author{
M.Ruhi Firdaus \\ Teknik Mesin, Fakultas Teknik \\ Universitas Maarif Hasyim Latif, Sidoarjo, Indonesia \\ e-mail : m-ruhi-firdaus@student.umaha.ac.id
}

\section{ABSTRAK}

Shaft driver adalah salah satu komponen yang berada dalam rangkain mesin hammer mill pembuat tepung.Berfungsi untuk penahan / penopang pulley, fly wheel, revolping disk.Shaft driver tersebut di gerakkan oleh motor TECO.Dengan spesifikasi mesin hammer mill yang sekarang sudah ada $50 \mathrm{HP}, 37 \mathrm{KW}$, 3 PHASE, 1465 RPM.Kerja yang begitu berat dan fungsi shaft driver yang sangat penting,Di butuhkan shaft driver yang kuat dan kokoh.Maka dari itu shaft driver ini harus melewati sebuah analisis atau perhitungan agar bisa kuat menopang beban fly wheel, pulley,dan revolping disk. Penelitian ini bertujuan untuk mengetahui pada titik lengkung, titik perpindahan, titik pertambahan panjang, titik luas area yang menerima beban dan fenomena perubahan yang terjadi, melakukan analisis material untuk mengetahui safety factor yang digunakan pada stainless 304.Dan melakukan simulasi dengan arah gaya, model, beban yang diterima shaft driver.Disini kami membuat analisis shaft driver mesin hammer mill ini menggunakan software Autodesk inventor professional 2015.Keuntungan menganalisis shaft driver di software Autodesk Inventor professional 2015 ini untuk membuat kemudahan bagi pengguna tanpa harus bersusah payah menghitung untuk mendesain shaft driver hammer mill dengan beban momen puntir dan lentur yang harus menopang pulley dan fly wheel.

Kata kunci: Autodesk inventor professonal 2015, Bronze, mesin Hammer mill, stainless 304, Steel mild, Shaftdriver

\section{PENDAHULUAN}

Di zaman era globalisasi ini semua di tuntut untuk semua serba cepat dan canggih.Begitu juga dalam dunia industri kami harus membuat alat yang kekinian untuk menjaga eksistensi dalam dunia permesinan.Karena dalam dunia industri semakin tahun semakin banyak bermunculan alatalat yang canggih. Ini juga yang terjadi Pada mesin pembuat tepung yang mumpunyai beberapa bentuk atau model. Permintaan yang sangat banyak.Maka ini harus ada inovasi untuk memakai sistem otomatis dan meninggalkan sistem manual. Dan yang tidak kalah penting nya yakni kualitas yang kita tawarkan.Kualitas dan kuantitas ini harus bisa berjalan beriringan untuk bisa bersaing di dunia pasar Dalam kondisi seperti ini kami menginginkan suatu alat yang canggih untuk menghancurkan beras yang banyak menghasilkan tepung tanpa butuh waktu yang lama dan memiliki kualitas tepung yang sempurna.

Disini kami memiliki solusi untuk membuatkan desain suatu mesin penghancur beras.Sebelum mesin ini di produksi kami ingin menganalisis terlebih dahulu mesin tersebut. Dan yang akan kami analisa yaitu pada bagian shaft driver nya.Analisis yang akan kami lakukan yakni
Von misses, Strees, Displacement, Strain.Karena shaft driver tersebut memiliki fungsi yang sangat penting untuk menghasilkan hasil tepung yang berkualitas bagus.Pada shaft driver tersebut ada beberapa part yang yang terakit yaitu pulley, roll drum rumah pisau, fly wheel.Yang semua komponen itu harus terpasang dengan baik dan harus seimbang (balance).

Untuk mengetahui shaft driver tersebut supaya bisa balance, maka kami mau menganalisis shaft driver tersebut terlebih dahulu menggunakan suatu aplikasi gambar yakni software autodesk inventor professional 2015.Kita bisa coba - coba pilih material apa yang akan kita gunakan di aplikasi tersebut, sebelum di kerjakan di produksi.Dengan kita mencoba-coba material yang banyak kita memiliki referensi, untuk memilih material yang harganya murah tanpa mempengaruhi hasil tepung tersebut. 


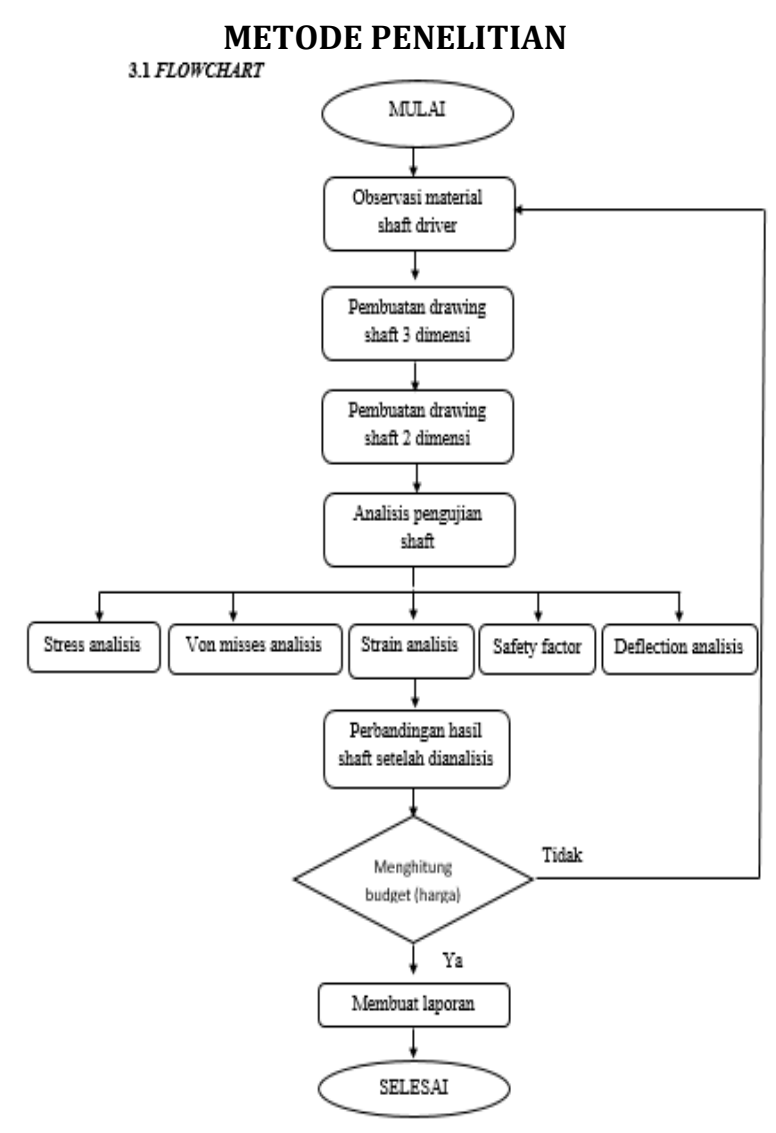

\subsubsection{0bservasi 3 macam material shaft driver}

Langkah awal dari penelitian analisis shaft driver ini yakni observasi 3 macam jenis material yang berbeda, untuk bahan perbandingan antara shaft driver satu dengan shaft driver lainnya.Ini berguna sebagai bahan referensi material apa yang nantinya akan dipergunakan untuk shaft driver hammer mill.Observasi ini bisa di lakukan di tokotoko material yang memiliki spek material dan bisa observasi diinternet dengan browsing-browsing.

\subsubsection{Pembuatan drawing shaft driver3 dimensi}

Langkah kedua yang harus dilakukan yaitu dengan membuat drawing (gambar) shaft driver 3 dimensi.Yang bertujuan untuk memberikan pengetahuan kepada orang yang tidak mengerti ilmu tehnik.Supaya bisa langsung paham apa yang akan di analisis bentuk $\mathrm{n}$

\subsubsection{Pembuatan drawing shaft driver 2 dimensi}

Langkah ketiga yang harus di lalui yaitu dengan membuat gambar tersebut menjadi 2 dimensi.Ini bertujuan supaya shaft tersebut bisa dibuat lebih detail lagi, karena 2 dimensi ini untuk memberi ukuran shaft tersebut baik dari diameter shaft maupun panjang shaft tersebut.

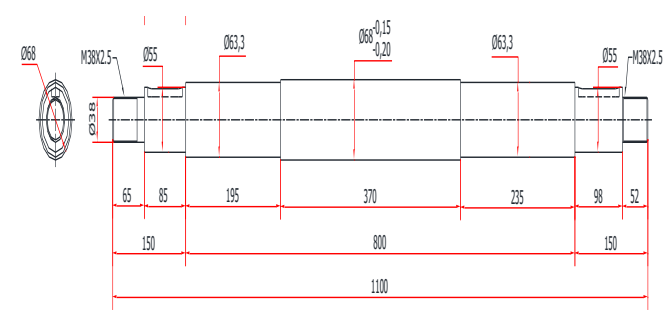

Gambar 1 shaft driver 2 dimensi

\subsubsection{Penganalisisan shaft driver menggunakan Autodesk Inventor Autodesk inventor professional 2015}

Untuk mengetahui berapa kekuatan dari shaft driver tersebut, maka perlu sebuah penganalisisan terlebih dahulu.Untuk menganalisis kekuatan shaft driver tersebut kami memakai software Autodesk inventor professional 2015.Yang mana dari penganalisisan tersebut bisa dilihat berapa kekuatan shaft driver.Dengan diberi beban pada salah satu sisi shaft driver.

\subsubsection{Hasil analisis yang di peroleh menggunakan software Autodesk Inventor professional 2015}

Dalam hasil analisis menggunakan software Autodesk Inventor professional 2015 didapatkan 5 hasil analisis yakni : Strees analysis, von misses analysis, Strain analysis, Safety factor, Deflection analysis.Untuk hasil analisis otomatis keluar 5 hasil analisis.Karena software Autodesk Inventor professional 2015 sudah memfasilitasi program yang digunakan untuk menganalisis sebuah part (shaft)

\section{HASIL DAN PEMBAHASAN}

Pada pengambilan data ini dilakukan di software Autodesk Inventor professional 2015 yang bisa digunakan untuk analisis.Adapun prinsip kerja/analisis shaft driver ini yakni memilih material yang akan digunakan kemudian memberi beban pada sisi yang akan menerima beban.Dan memasukkan gaya gravitasi yang di peroleh kemudian pilih simulation. Di bawah ini gambar dari mesin hammer mill yang dirakit lengkap dan gambar hopper nya saja.Karena yang akan kami bahas shaft driver nya . 


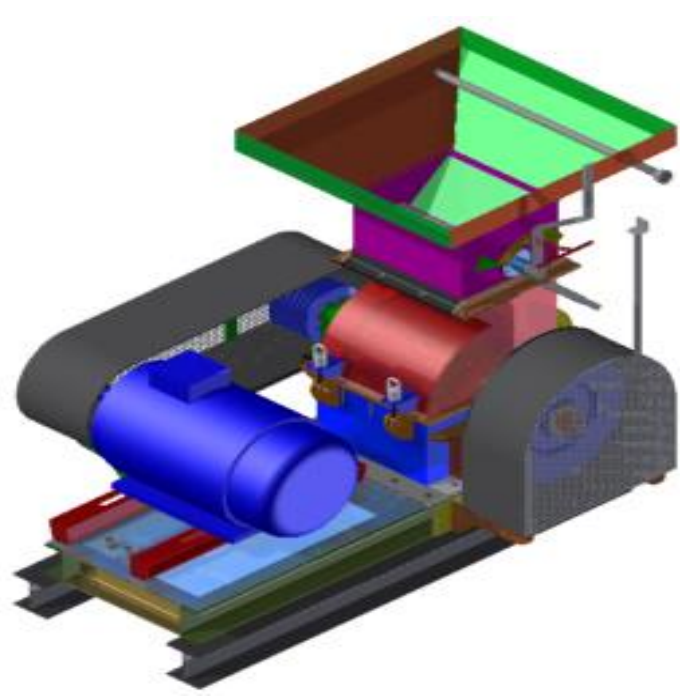

(Gambar 2 hammer mill full)

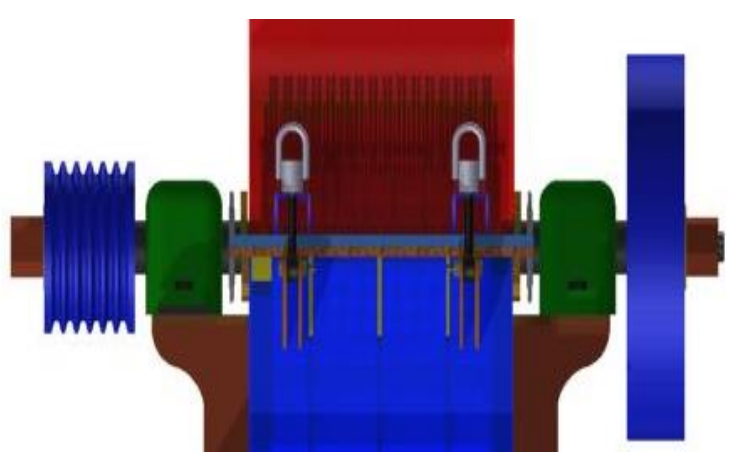

Gambar 3 detail shaft driver

Lagkah pertama yang harus dilakukan ketika membuat analisis shaft driver yaitu memasukkan angka -angka dan sebagainya yang ada hubungan nya dengan shaft yang sudah disediakan oleh software Autodesk inventor professional 2015.Diantara nya:

1. Material yang digunakan

2. Titik tetap (titik yang tidak bisa berubah)/fix location

3. Gaya yang diterima

4. Beban yang diterima

5. Momen puntir yang diterima

6. Gaya gravitasi

Pertama adalah pemilihan material yang akan digunakan untuk menganalisis shaft driver hammer mill.Di software Autodesk inventor di fasilitasi macammacam material.kami tinggal memilih material apa yang akan kita gunakan

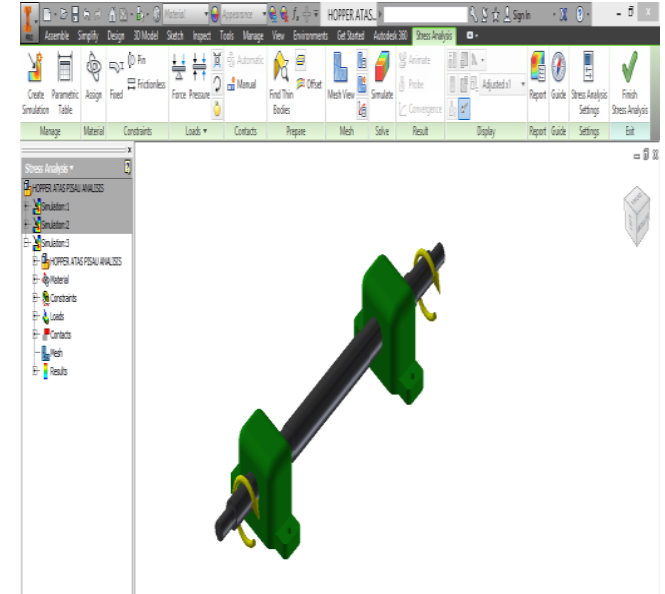

Gambar 4 pemilihan material

Kedua adalah fixed geometry (Tumpuan mati).Perintah ini kita disuruh memberi tumpuan mati yang tidak akan bergerak.Untuk shaft driver hammer mill ini tumpuan yang tidak bergerak yakni pillow block.Maka tumpuan matinya di berikan di pillow block.

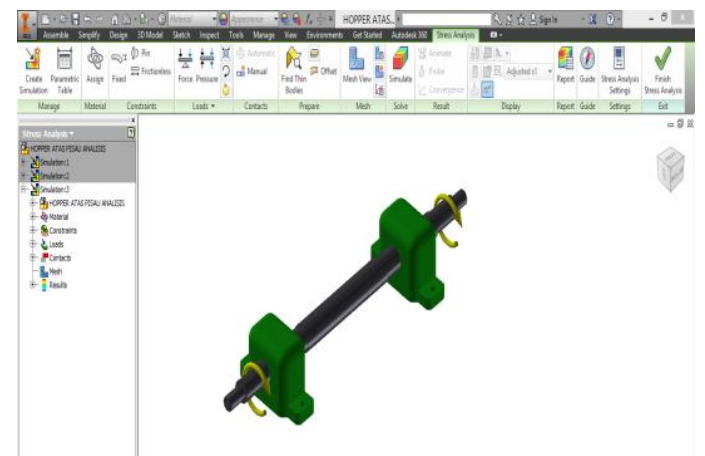

Gambar 5 fixed geometry (tumpuan mati)

Tahap selanjutnya memberi beban puntir pada shaft driver hammer mill.Momen puntir ini didapatkan dari beban roda gila (fly wheel), puli (pulley).Karena pada saat shaft driver berputar mengalami gaya gravitasi.

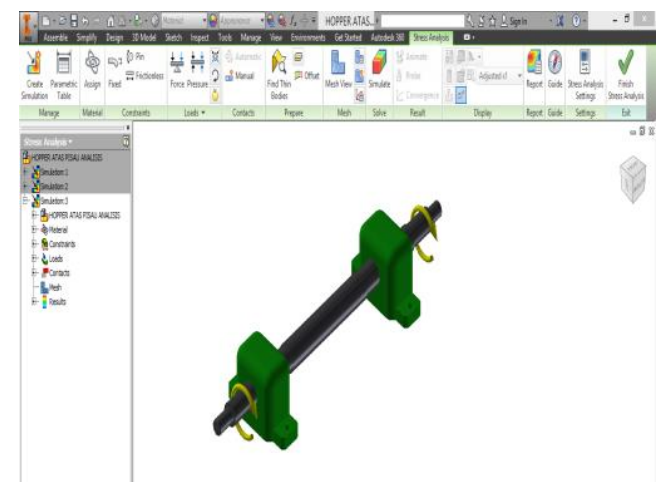

Gambar 6 pemeberian momen puntir

Proses simulasi yang sedang dilakukan (processing simulation) dapat dilihat pada gambar dibawah ini. 


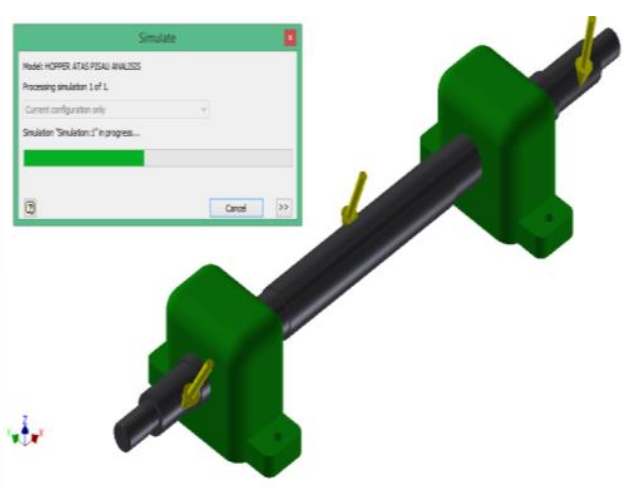

Gambar 7 (processing simulation)

Dan akan muncul langsung lima analisis yang dapat ditampilkan secara otomatis pada software Autodesk inventor 2015 yaitu :
1. Von Misses Result
2. Displacement Result
3. Strain Result
4. Stress Result
5. Safety Factor

\section{Penulisan Persamaan Matematika}

Dasar teori perhitungan yang akan dilakukan adalah perhitungan shaft driver hammer mill dengan momen puntir dan lentur yang tegangan maksimalnya belum diketahui, maka rumus yang akan dipakai adalah sebagai berikut :

\section{a. Rumus kekuatan tarik}

\section{$\sigma=32 \mathrm{M} / \pi \cdot d s^{3}$}

Ket :

$\boldsymbol{\sigma}=$ Bending Stress Poros ( N/m2)

$\mathrm{M}=$ Moment Lentur ( F . x ) Gaya dikali Jarak gaya ( N.m )

$$
\pi=\operatorname{Phi}(22 / 7)
$$

$\mathrm{ds}=$ Diameter ( $\mathrm{r} \times 2$ ) Radius/Jari-jari dikali Dua ( $\mathrm{m}$ )

(Rumus dari Sularso dan Suga )

\section{b. Rumus tegangan geser shaft}

\section{$\tau=16 \mathrm{~T} / \pi \cdot d \mathrm{~s}^{3}$}

\section{Ket :}

$\boldsymbol{\tau}=$ Tegangan Geser Poros $(\mathrm{N} / \mathrm{m} 2)$

$\mathrm{T}=$ Torsi $(\mathrm{N} . \mathrm{m})$

$\pi=\operatorname{Phi}(22 / 7)$

ds = Diameter ( r x 2 ) Radius/Jari-jari dikali Dua ( $\mathrm{m}$ )

(Rumus dari Sularso dan Suga )

\section{c. Rumus Moment Lentur Poros}

Ket :

$$
\mathrm{M}=\mathrm{F} \cdot \mathrm{X}
$$

$\mathrm{M}=$ Moment Lentur / Bending ( N.m )

$\mathrm{F}=$ Gaya yang diterima poros $(\mathrm{N})$

$\mathrm{x}=$ Jarak Gaya $(\mathrm{m})$

\author{
d. Rumus Torsi Poros \\ $\mathrm{T}=(60.000 /((22 / 7) \times 2)) \times(\mathrm{P} / \mathrm{n})$ \\ Ket : \\ $\mathrm{T}=$ Torsi / Moment Puntir ( N.m ) \\ $\mathrm{P}=$ Daya $(\mathrm{KW})$ \\ $\mathrm{n}=\operatorname{Putaran}(\mathrm{Rpm})$ \\ ( Rumus dari Sularso yang satuannya telah diubah)
}

e. Rumus Gaya yang diterima poros

$$
F=\frac{(\mathrm{Bp}+\mathrm{Bf}) \cdot \mathrm{g}}{2}
$$

$\mathrm{F}=$ Gaya yang diterima poros $(\mathrm{N})$

$\mathrm{Bp}=$ Berat Pulley $(\mathrm{Kg})$

$\mathrm{Bf}=$ Berat fly wheel $(\mathrm{Kg})$

$\mathrm{g}=$ Gravitasi 9.81

\section{Perhitungan Manual}

Data yang di ketahui

$\begin{array}{lll}\text { Daya mesin } & =37 \mathrm{kw} \\ \text { Putaran mesin }(\mathrm{rpm}) & =1465 \mathrm{rpm} \\ \text { Berat pulley } & =25,5 \mathrm{~kg} \\ \text { Berat fly wheel } & =102,5 \mathrm{~kg} \\ \text { Gravitasi } & =9,8 \mathrm{~m} / \mathrm{s}^{2} \\ \pi \text { (phi) } & =22 / 7(3,14) \\ \text { Diameter shaft } & =55 \mathrm{~mm}(0,055 \mathrm{~m})\end{array}$

Tegangan lentur $(\sigma)$ shaft $=30.737 .072,61 \mathrm{~N} / \mathrm{m}^{2}$

Tegangan puntir $(\tau)$ shaft $=7.313 .683,679 \mathrm{~N} / \mathrm{m}^{2}$

Torsi poros $\quad=238,8 \mathrm{~N} / \mathrm{m}$

Momen lentur poros $\quad=501,8 \mathrm{~N} / \mathrm{m}$

\section{a. Rumus Gaya yang diterima poros}

$$
\begin{aligned}
F & =\frac{(\mathrm{Bp}+\mathrm{Bf}) \cdot \mathrm{g}}{2} \\
F & =\frac{(25,5+102,5) \cdot 9,8}{2} \\
& =\frac{(1.254,4)}{2} \\
& =627,2 \mathrm{~N}
\end{aligned}
$$

\section{b. Rumus torsi poros}

$$
\begin{aligned}
\mathrm{T} & =(60.000 /((\pi) \times 2)) \times(\mathrm{P} / \mathrm{n}) \\
& =(60.000 /((3,14) \times 2)) \times(37 / 1465) \\
& =(60.000 / 6,28) \times(0,025) \\
& =(9.554 \times 0,025) \\
& =238,8 \mathrm{~N} / \mathrm{m}
\end{aligned}
$$

\section{c. Momen lentur poros}

$$
\begin{aligned}
M & =F \cdot x \\
M & =627,2 \mathrm{~N} \cdot 0,8 \mathrm{~m} \\
& =501,8 \mathrm{~N} / \mathrm{m}
\end{aligned}
$$




\section{d. Rumus tegangan geser poros}

$$
\begin{aligned}
\tau & =\frac{(16 \mathrm{~T})}{\pi \cdot d s^{3}} \\
\tau & =\frac{16 \times 238,8}{3,14 \cdot 0,055^{3}} \\
\tau & =\frac{3.820,8}{0,00052} \\
& =7.313 .683,679 \mathrm{~N} / \mathrm{m}^{2}
\end{aligned}
$$

\section{Gambar dan Tabel}

\section{Tabel spesifikasi material}

\section{Mechanical Properties}

Tabel 3.1 Mechanical Properties AISI 4140 Steel Alloys

\begin{tabular}{|l|r|}
\hline \multicolumn{1}{|c|}{ Properties } & \multicolumn{1}{c|}{ Metric } \\
\hline Tensile strength & $655 \mathrm{Mpa}$ \\
\hline Yield strength & $460 \mathrm{Mpa}$ \\
\hline Bulk modulus (typical for steel) & $140.000 \mathrm{Mpa}$ \\
\hline Shear modulus (typical for steel) & $80.000 \mathrm{Mpa}$ \\
\hline Elastic modulus & $205.000 \mathrm{Mpa}$ \\
\hline Poisson's ratio & 0.29 \\
\hline Mass density & $7850 \mathrm{Kg} / \mathrm{m}^{3}$ \\
\hline Thermal conductivity $\left(@ 100^{\circ} \mathrm{C}\right)$ & $42.7 \mathrm{~W} /(\mathrm{m} \cdot \mathrm{K})$ \\
\hline Sumber : (Azom, 2012) &
\end{tabular}

\section{Chemical Composition}

Tabel 3.2 Chemical Composition AISI 4140 Steel Alloys

\begin{tabular}{|l|r|}
\hline \multicolumn{1}{|c|}{ Element } & \multicolumn{1}{|c|}{ Content (\%) } \\
\hline Chromium, Cr & $0.80-1.10$ \\
\hline Manganese, Mn & $0.75-1.0$ \\
\hline Carbon, $C$ & $0.380-0.430$ \\
\hline Silicon, Si & $0.15-0.30$ \\
\hline Molybdemum, Mau & $0.15-0.25$ \\
\hline Sulfur, S & 0.040 \\
\hline Phosphorous, $P$ & 0.035 \\
\hline
\end{tabular}

Sumber : (Azom, 2012)

Von misses adalah analisis untuk mengetahui titik dimana tekanan yang terbesar muncul.Untuk menganalisis shaft ini di memberikan gaya puntir,karena shaft tersebut berputar.dan perubahan lengkung yang terjadi sebesar 7,8 maksimal.dari hasil analisis von misses tersebut dapat diketahui dengan melihat perubahan warna yg terjadi dimana warna merah menunjukkan tekanan yang terbesar sedangkan warna biru tidak menerima tekanan sama sekali.

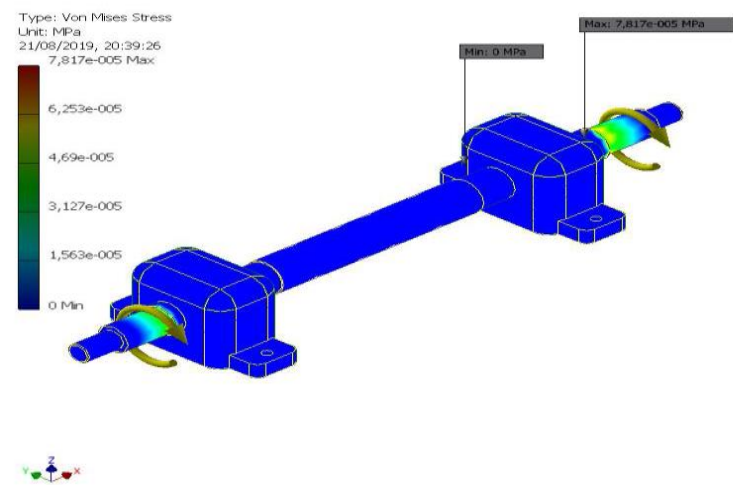

Gambar 8 simulasi von misses material Steel mild

Displacement adalah analisis yang menunjukkan perpindahan/lendutan dari posisi awal sampai posisi terlengkung ketika menerima sebuah tekanan,yang ditunjukkan dengan satuan mm., dari hasil displacement tersebut dapat diketahui dengan melihat perubahan warna.Untuk hasil analisis shaft driver hammer mill ini menghasilkan perpindahan panjang 2,7 $\mathrm{mm}$ maksimal .Untuk menjelaskan Warna merah menunjukkan perpindahan jarak terjauh dari titik awal.

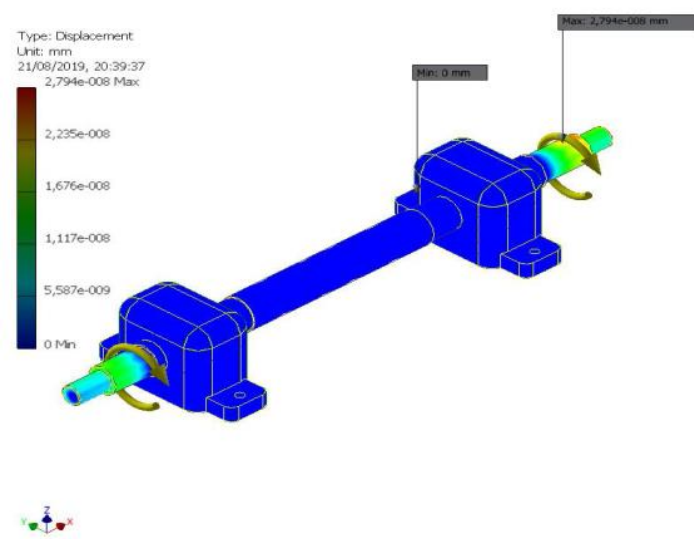

Gambar 9 simulasi displacement material Steel mild

Strain Perbandingan antara pertambahan panjang batang dengan panjang mula-mula ada daerah elastis, besarnya tegangan berbanding lurus dengan regangan. Perbandingan antara tegangan dan regangan benda tersebut disebut modulus elastisitas atau modulus young. Jika pada simulasi menghasilkan nilai maksimum dan bagian part yang menerima gaya lalu berubah berwarna merah ataupun kuning part tersebut mengalami regangan yang diakibatkan tegangan maksimal yang berada pada daerah tersebut.Dari hasil analisis shaft driver hammer mill tidak mengalami pertambahan panjang karena shaft sudah bisa menahan bebannya. 


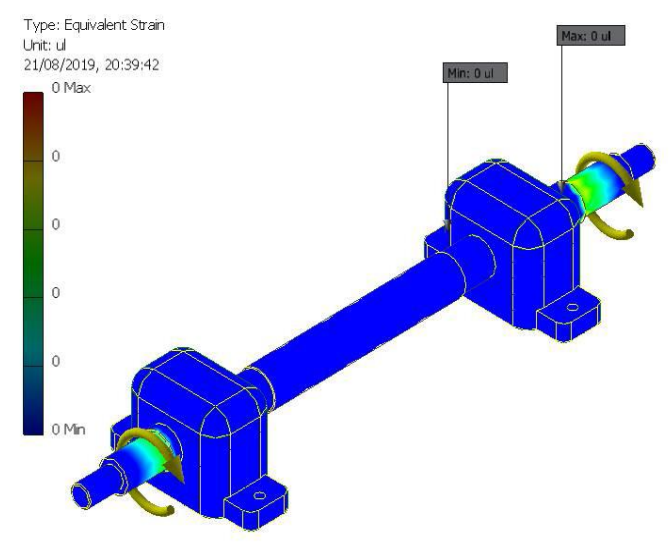

$$
0^{2} \cdot 6
$$

Gambar 10 simulasi strain material Steel mild

strees adalah analisis yang menunjukkan luas area yang menerima beban gaya dengan pembagian luas bidang yang terkena tekanan, dari hasil analisis strees tersebut dapat diketahui dengan melihat perubahan warna yg terjadi dimana warna merah menunjukkan tekanan yang terbesar sedangkan warna biru menunjukkan tekanan yang terkecil.Hasil analisis shaft yang di hasilkan 8,1 Mpa maksimal.
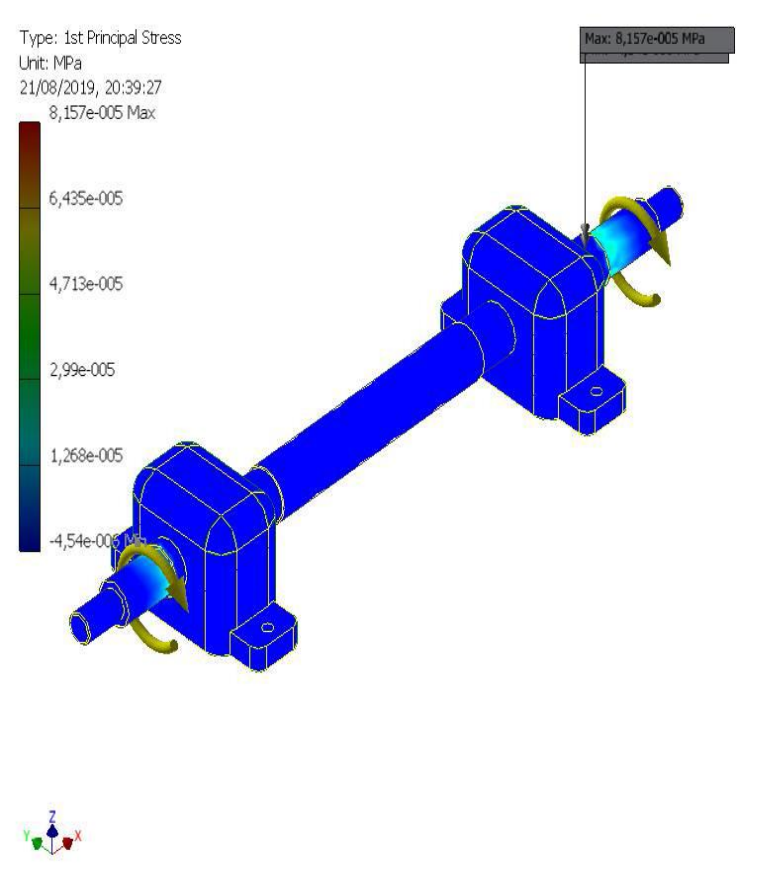

Gambar 11 simulasi stress material Steel mild

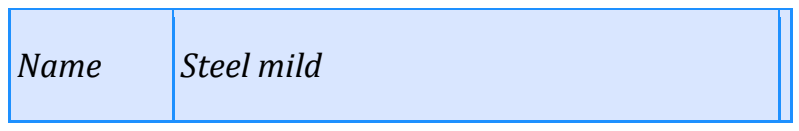

Safety factor adalah faktor yang digunakan utk mengevaluasi keamanan dari suatu desain.Dimana kisaran faktor dari 1 sampai 15 faktor keamanan yang baik harus lebih dari 1 utk menghindari terjadinya kegagalan suatu desain.Warna biru menunjukkan desain paling aman.Dan warna merah menunjukkan desain di luar batas aman.

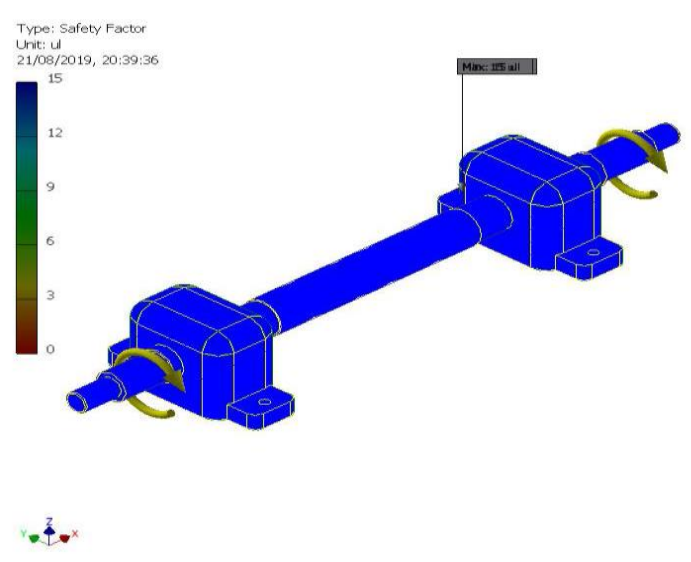

Gambar 12 analisis safety factor material Steel mild

strees adalah analisis yang menunjukkan luas area yang menerima beban gaya dengan pembagian luas bidang yang terkena tekanan, dari hasil analisis strees tersebut dapat diketahui dengan melihat perubahan warna yg terjadi dimana warna merah menunjukkan tekanan yang terbesar sedangkan warna biru menunjukkan tekanan yang terkecil.Hasil analisis shaft yang di hasilkan 7,9 Mpa maksimal

Tabel 4.1 Spesifikasi material Steel mild

\begin{tabular}{|l|l|l|}
\hline \multirow{4}{*}{ Name } & \multicolumn{2}{|l|}{ Iron, Cast } \\
\hline \multirow{4}{*}{ Streneral } & Mass Density & $7,15 \mathrm{~g} / \mathrm{cm}^{\wedge} 3$ \\
\cline { 2 - 3 } & Yield Strength & $758 \mathrm{MPa}$ \\
\cline { 2 - 3 } & $\begin{array}{l}\text { Ultimate Tensile } \\
\text { Strength }\end{array}$ & $884 \mathrm{MPa}$ \\
\hline & Young's Modulus & $120,5 \mathrm{GPa}$ \\
\cline { 2 - 3 } & Poisson's Ratio & $0,3 \mathrm{ul}$ \\
\cline { 2 - 3 } & Shear Modulus & $46,3462 \mathrm{GPa}$ \\
\hline \multirow{2}{*}{$\begin{array}{l}\text { Part } \\
\text { Name(s) }\end{array}$} & $\begin{array}{l}\text { PILLOW } \\
\text { PILLOW }\end{array}$ \\
\hline \multirow{2}{*}{ General } & Mass Density & $8 \mathrm{~g} / \mathrm{cm}^{\wedge} 3$ \\
\hline
\end{tabular}




\begin{tabular}{|l|l|l||}
\hline \multirow{2}{*}{} & Yield Strength & $228 \mathrm{MPa}$ \\
\cline { 2 - 3 } & $\begin{array}{l}\text { Ultimate Tensile } \\
\text { Strength }\end{array}$ & $540 \mathrm{MPa}$ \\
\hline Stress & Young's Modulus & $190,3 \mathrm{GPa}$ \\
\hline
\end{tabular}

\begin{tabular}{|l|l|l||}
\hline \multirow{2}{*}{} & Poisson's Ratio & $0,305 \mathrm{ul}$ \\
\cline { 2 - 3 } & Shear Modulus & $72,9119 \mathrm{GPa}$ \\
\hline $\begin{array}{l}\text { Part } \\
\text { Name(s) }\end{array}$ & SHAFT PILLOW \\
\hline
\end{tabular}

\section{Tabel summary}

\begin{tabular}{|c|c|c|}
\hline Name & Minimum & Maximum \\
\hline Volume & \multicolumn{2}{|l|}{$9286640 \mathrm{~mm}^{\wedge} 3$} \\
\hline Mass & \multicolumn{2}{|l|}{$69,1585 \mathrm{~kg}$} \\
\hline Von Mises Stress & $0 \mathrm{MPa}$ & 0,000079051 MPa \\
\hline $\begin{array}{l}\text { 1st Principal } \\
\text { Stress }\end{array}$ & $\begin{array}{l}-0,00000526319 \\
\mathrm{MPa}\end{array}$ & $0,0000790588 \mathrm{MPa}$ \\
\hline $\begin{array}{l}\text { 3rd Principal } \\
\text { Stress }\end{array}$ & $-0,000087586 \mathrm{MPa}$ & $0,00000303894 \mathrm{MPa}$ \\
\hline Displacement & $0 \mathrm{~mm}$ & $0,0000000330219 \mathrm{~mm}$ \\
\hline Safety Factor & $15 \mathrm{ul}$ & $15 \mathrm{ul}$ \\
\hline Stress XX & $-0,0000589937 \mathrm{MPa}$ & $0,0000532452 \mathrm{MPa}$ \\
\hline Stress $X Y$ & $-0,0000368288 \mathrm{MPa}$ & $0,0000367813 \mathrm{MPa}$ \\
\hline Stress XZ & $-0,000035727 \mathrm{MPa}$ & $0,0000416758 \mathrm{MPa}$ \\
\hline Stress YY & $-0,0000358856 \mathrm{MPa}$ & $0,0000365764 \mathrm{MPa}$ \\
\hline Stress YZ & $-0,0000291355 \mathrm{MPa}$ & $0,0000262933 \mathrm{MPa}$ \\
\hline Stress ZZ & $-0,0000473671 \mathrm{MPa}$ & $0,0000424418 \mathrm{MPa}$ \\
\hline X Displacement & $\begin{array}{l}-0,00000000274615 \\
\mathrm{~mm}\end{array}$ & $0,00000000293381 \mathrm{~mm}$ \\
\hline Y Displacement & $\begin{array}{l}-0,0000000301322 \\
\mathrm{~mm}\end{array}$ & $0,0000000293458 \mathrm{~mm}$ \\
\hline Z Displacement & $\begin{array}{l}-0,0000000261684 \\
\mathrm{~mm}\end{array}$ & $0,0000000330197 \mathrm{~mm}$ \\
\hline Equivalent Strain & $0 \mathrm{ul}$ & $0,000000000374541 \mathrm{ul}$ \\
\hline 1st Principal & $\begin{array}{l}- \\
0,000000000000000\end{array}$ & $0,00000000041514 \mathrm{ul}$ \\
\hline
\end{tabular}

\begin{tabular}{|c|c|c|}
\hline Strain & $00039659 \mathrm{ul}$ & \\
\hline $\begin{array}{l}\text { 3rd Principal } \\
\text { Strain }\end{array}$ & $\begin{array}{l}- \\
\text { ul } \\
\text { ul }\end{array}$ & $\begin{array}{l}0,000000000000000236 \\
839 \text { ul }\end{array}$ \\
\hline Strain $X X$ & $\begin{array}{l}0,000000000235227 \\
\text { ul }\end{array}$ & 0,000000000238121 ul \\
\hline Strain $X Y$ & $\begin{array}{l}- \\
0,000000000252557 \\
\text { ul }\end{array}$ & $0,000000000252231 \mathrm{ul}$ \\
\hline Strain $X Z$ & $\begin{array}{l}- \\
0,000000000245001 \\
\text { ul }\end{array}$ & $0,000000000285796 \mathrm{ul}$ \\
\hline Strain $Y Y$ & $\begin{array}{l}0,000000000223331 \\
\text { ul }\end{array}$ & 0,000000000237049 ul \\
\hline Strain $Y Z$ & $\begin{array}{l}\text { 0,000000000199799 } \\
\text { ul }\end{array}$ & 0,000000000180308 ul \\
\hline Strain ZZ & $\begin{array}{l}- \\
0,000000000201369 \\
\text { ul }\end{array}$ & 0,000000000186293 ul \\
\hline Contact Pressure & $0 \mathrm{MPa}$ & $0 \mathrm{MPa}$ \\
\hline
\end{tabular}

\section{PENUTUP}

\section{Kesimpulan}

Dari penelitian yang sudah dilakukan, penulis dapat menarik beberapa kesimpulan, antara lain : 1. Hasil perhitungan desain poros dengan perhitungan manual antara lain :

a. Torsi pada Poros : 814,545 N.m

d. Beban yang diterima pada Poros : 627,2 N

e. Moment Lentur pada Poros : 501,8 N/m

f. Kekuatan Tarik pada Poros : 30.737.072,61 $\mathrm{N} / \mathrm{m}^{2}$ 
g. Tegangan Geser pada Poros : 7.313.683,679 $\mathrm{N} / \mathrm{m}^{2}$

Nilai yang diketahui antara lain :
a. Daya mesin : $37 \mathrm{KW}$
b. Putaran mesin : $1465 \mathrm{rpm}$
c. Berat Pulley : $25,5 \mathrm{~kg}$
d. Berat fly wheel : $102,5 \mathrm{~kg}$
e. Jarak beban poros : $0.1 \mathrm{~m}$
f. Diameter terkecil poros: : $0.5 \mathrm{~m}$

2. Software Optimasi Desain Shaft (dengan Beban Puntir dan Lentur) yang dibuat menggunakan Autodesk inventor 2015 berjalan dengan lancar tanpa kendala, ketika nilai - nilai yang diketahui dimasukan dan hal ini bisa dilakukan dengan data yang berbeda, selain itu pilihan data yang ingin diketahui pun lengkap sesuai data spesifikasi shaft.

3. Hasil simulasi desain poros menunjukkan bahwa tegangan pada :

Autodesk inventor : 7,9 Mpa (analisis von misses ) Manual $\quad: 7.313 .683,679 \mathrm{~N} / \mathrm{m}^{2} \quad=7,3 \mathrm{Mpa}$

Perhitungan manual

Hasil perhitungan manual lebih kecil dari hasil perhitungan program simulasi karena pada program simulasi terdapat bagian poros yang diameternya paling kecil sementara itu nilai hasil perhitungan manual menunjukkan nilai tiga kali lebih kecil dari pada hasil simulasi pada benda uji, pada properties material tiap program menunjukan spesifikasi yang tidak sama persis. Pada Autodesk inventor penguji menggunakan material Steel mild dan biasaynya memiliki spesifikasi yang berbeda.

\section{Saran}

Setelah peneliti melakukuan penelitian ini maka hasilnya tidaklah selalu sempurna sesuai dengan apa yang diinginkan, maka penulis memberi saran antara lain :

1. Ketika melakukan penelitian didalam komputer, maka dokumentasi (foto layar) tidak boleh terlupakan di setiap tahap prosesnya, karena terdapat tahap yang tidak bisa dilakukan secara berulang.

2. Ketika mendapatkan data dari berbagai sumber, maka teliti pada satuannya, terlebih lagi harus disamakan dahulu satuannya, karena setiap sumber menggunakan satuan yang berbeda, sesuai dengan yang mereka anggap nyaman atas satuan yang mereka gunakan.

3. Dalam pengukuran benda uji untuk memperoleh data yang akurat, diperlukan ketelitian dari segi visual, skill, maupun pengetahuan, karena kelalaian sedikit diawal mampu membuat kesalahan yang fatal.

\section{DAFTAR PUSTAKA}

Achmad, N. H., \& Ngadiyono, Y. (2016). Pengembangan Modul Pembelajaran Inventor Berbasis Contextual Teachingand Learning (Ctl) Di Smk Muhammadiyah 1 Bantul. Jurnal Pendidikan Vokasional Teknik Mesin, 4(2), 131-136.

Afifah, Y. N. (2016). ALIRAN TAK TUNAK FLUIDA NANO MAGNETOHIDRODINAMIK ( MHD ) YANG MELEWATI BOLA.

Afifah, Y. N. (2019). (2019). Analysis of Unsteady Magneto Hydro Dynamic ( MHD ) Nano Fluid Flow Past A Sliced Sphere Analysis of Unsteady Magneto Hydro Dynamic ( MHD ) Nano Fluid Flow Past A Sliced Sphere. IOP Conference Series: Materials Science and Engineering, 494, 012033. https://doi.org/10.1088/1757899X/494/1/012033

Afifah, Y. N., \& Putra, B. C. (2018). Model Matematika Aliran Tak Tunak Pada Nano Fluid Melewati Bola Teriris Dengan Pengaruh Medan Magnet. Teknika: Engineering and Sains Journal, 2(2), 119-124.

Asroni, A. (2015). Stress Analysis Pada Stand Shock Absorbers Sepeda Motor Dengan Menggunakan Software Inventor 2015. Turbo: Jurnal Program Studi Teknik Mesin, $4(1)$, 23-27. https://doi.org/10.24127/trb.v4i1.4

Roni wandra,yohanes, mustafa akbar. (2016). Desain Mesin Penghancur (Shredder Machine) Batang Kelapa Sawit Berbasis Metode Design For Manufacture and Assembly (DFMA).

Sabardiyanto, \& Iskandar, N. (2016). ANALISIS MEKANIK SCREW CONVEYOR TUBULAR DIAMETER 200 mm. Teknik Mesin, 4(2), 178186.

Setyono, B. (2016). Perancangan Dan Analisis Kekuatan Frame Sepeda Hibrid "Trisona" Menggunakan Software Autodesk Inventor. Jurnal IPTEK, 20(2), 37. https://doi.org/10.31284/j.iptek.2016.v20i2. 43

Wibawa, L. A. N. (2019). Desain Dan Analisis Tegangan Crane Hook Model Circular Section Kapasitas 5 Ton Menggunakan Autodesk Inventor 2017. Simetris: Jurnal Teknik Mesin, Elektro Dan Ilmu Komputer, 10(1), 27-32. https://doi.org/10.24176/simet.v10i1.2669 